\title{
Evaluation of physical, nutritional and sensory characteristics of cookies developed with bio-fortified pearl millet
}

\author{
Priti G. Kale, K. P. Babar, D. T. Bornare and P. R. Vairagar
}

\begin{abstract}
This study examines the effect of pearl millet varieties bio-fortified $A H B 1200 \mathrm{Fe}$ and MRB (Aurangabad Hybrid Bajra and Maharashtra Rabi Bajra, respectively) as a replacement of whole wheat flour at various levels on quality of cookies. For improving nutritional composition germination treatment was given to both varieties. Before making cookies germination effect was analyses on two varieties of pear millet for proximate, mineral and on anti-nutritional. This raw material analysis revealed that protein was increased and ash, fat, fibre is decreased but availability of minerals was increased due to decreasing level of anti-nutritional upto 40-45 per cent. Enriched cookies were produced by the ratio of whole wheat to pearl millet was 100:00, 80:20, 70:30, 60:40 and 50:50. Cookies were prepared by four types of pearl millet flour (Two varieties and one treatment with wheat flour using these five ratios. From each type of flour one sample was selected on the basis of sensory analysis. And these selected four types of cookies were evaluated for chemically and physical characteristics. Physical characteristics of cookies shows that the diameter and spread ratio is increased slightly as compare to control but did not very markedly. Germination is lightly affected on physical properties but varieties were not markedly affecting. The overall results indicated that the positive response of pearl millet flour substitution to whole wheat flour upto 30 and 40 per cent in preparation of cookies germinated and without germinated, respectively.
\end{abstract}

Key Words : Anti-nutritional, Cookies, Germination, Mineral, Pearl millet

How to cite this article : Kale, Priti G., Babar, K.P., Bornare, D.T. and Vairagar, P.R. (2018). Evaluation of physical, nutritional and sensory characteristics of cookies developed with bio-fortified pearl millet. Food Sci. Res. J., 9(2): 223-230, DOI : 10.15740/HAS/ FSRJ/9.2/223-230. Copyright@ 2018: Hind Agri-Horticultural Society.

MEMBERS OF RESEARCH FORUM

Author for correspondence :

Priti G. Kale, Department of Agricultural Engineering, Maharashtra

Institute of Technology, Aurangabad (M.S.) India

(Email : pritikale492@gmail.com)

Associate Authors' :

K.P. Babar and D.T. Bornare, Department of Agricultural Engineering, Maharashtra Institute of Technology, Aurangabad (M.S.) India

P. R. Vairagar, Food Science and Technology, Maharashtra Institute of Technology, Aurangabad (M.S.) India 